\title{
Can Trust Motivate Farmers to Purchase Natural Disaster Insurance? Evidence from Earthquake-Stricken Areas of Sichuan, China
}

\author{
Xueling Bao ${ }^{1}$, Fengwan Zhang ${ }^{1}$, Xin Deng ${ }^{2}$ and Dingde $X \mathbf{u}^{1,3, * \mathbb{D}}$ \\ 1 College of Management, Sichuan Agricultural University, Chengdu 611130, China; \\ baoxueling@stu.sicau.edu.cn (X.B.); zhangfengwan@stu.sicau.edu.cn (F.Z.) \\ 2 College of Economics, Sichuan Agricultural University, Chengdu 611130, China; dengxin@sicau.edu.cn \\ 3 Sichuan Center for Rural Development Research, College of Management, Sichuan Agricultural University, \\ Chengdu 611130, China \\ * Correspondence: dingdexu@sicau.edu.cn; Tel.: +86-134-0859-8819
}

Citation: Bao, X.; Zhang, F.; Deng, X. $\mathrm{Xu}, \mathrm{D}$. Can Trust Motivate Farmers to Purchase Natural Disaster Insurance? Evidence from Earthquake-Stricken Areas of Sichuan, China. Agriculture 2021, 11, 783. https://doi.org/ 10.3390/agriculture11080783

Academic Editor: Terence J. Centner

Received: 28 July 2021

Accepted: 15 August 2021

Published: 17 August 2021

Publisher's Note: MDPI stays neutral with regard to jurisdictional claims in published maps and institutional affiliations.

Copyright: (c) 2021 by the authors. Licensee MDPI, Basel, Switzerland. This article is an open access article distributed under the terms and conditions of the Creative Commons Attribution (CC BY) license (https:/ / creativecommons.org/licenses/by/ $4.0 /)$.

\begin{abstract}
Natural disasters cause great losses of property and life in many areas of China. However, rural residents do not always insure themselves against these losses. Measuring the correlation between trust and farmers' behavior related to the purchasing of natural disaster insurance is of great significance to the implementation of natural disaster insurance pilot programs and insurance systems in China. This article analyzes data from a survey of 327 households in four districts and counties of Sichuan Province, China, that were affected by the Wenchuan and Lushan earthquakes. According to the relevant theories of trust, trust was divided into three dimensions: authority trust, collective trust, and relationship trust. Then a technology acceptance model was built, and PLS-SEM was used to comprehensively analyze the correlation between different dimensions of trust and farmers' insurance purchase behavior. The results show that (1) only relationship trust was directly and significantly positively correlated with insurance purchasing behavior. Although there was no direct significant correlation between authoritative trust or collective trust and buying behavior, relationship trust was found to indirectly affect buying behavior. (2) Younger farmers and those with higher incomes are more likely to buy disaster insurance if they live in a disaster-threat zone, have experienced disasters, and are risk averse. We then discuss the correlations between farmers' trust and natural disaster insurance purchasing in areas threatened by earthquake disasters. This provides a policy inspiration for the promotion of disaster insurance and the construction of insurance systems in China.
\end{abstract}

Keywords: trust; natural disaster insurance; PLS-SEM; technology acceptance model; correlation judgment

\section{Introduction}

Natural disasters refer to events in which abnormal changes in nature exceed the tolerance that humans can bear [1,2], resulting in human casualties, property losses, social instability, resource destruction, and other phenomena or a series of injuries to human society and economy, mainly including geophysical disasters (such as earthquakes and volcanoes) and climate-induced disasters (such as floods, storms, and landslides) [3-6]. China is a large mountainous country in which hilly areas account for $70 \%$ of the total land area and host about $45 \%$ of the population [7-14]. Influenced by geology and geomorphology, mountainous areas have been prone to natural disasters since ancient times $[15,16]$. Their disasters are characterized by chain reactions and mass occurrences [17-21]. This makes China one of the countries with the worst natural disasters in the world [22-24]. Sichuan Province is one of the most famous earthquake disaster regions in the world and suffers great losses from earthquakes $[25,26]$. Some 204 earthquakes of magnitude $\geq 5$ occurred 
in China from 2004 to 2019, causing 561,800 casualties and direct economic losses of RMB 1.14 trillion [27]. Among them, the Wenchuan earthquake of 12 May 2008 and the Lushan earthquake of 20 April 2013 were magnitude $\geq 7$ and caused about 450,000 casualties and more than RMB 900 billion in direct economic losses. For residents of some areas, natural disasters are inevitable. They cause huge losses that far exceed the residents' ability to bear [28-31]. As early as 1991, some scholars put forward theories related to behavioral insurance and risk aversion, and now these theories have been used maturely [32]. In this context, natural disaster insurance came into being [33,34]. At present, natural disaster insurance refers to the institutional arrangement of risk diversification and economic compensation in the form of insurance by a government or other public organizations $[35,36]$. It uses the insurance mechanism to mitigate the huge property losses and serious casualties caused by natural disasters, such as earthquakes, hurricanes, tsunamis, and floods [37]. Although natural disaster insurance has been implemented in China for several years, some studies have found that the proportion of farmers purchasing natural disaster insurance is low [38]. Is this because local governments do not promote insurance sufficiently? Is it that local residents do not trust insurance schemes to protect people and property? This is an anomaly well worth studying. Improving the insurance purchasing intentions and behaviors of residents of natural disaster areas, especially disaster areas, has become a difficult problem in academic and political circles.

The main research question is: why do only a small proportion of people at risk of natural disasters purchase disaster insurance? Some scholars have analyzed this phenomenon by considering the roles of governmental/societal assistance and insurance, finding that the former has a "crowding-out effect" on residents' insurance purchasing $[39,40]$. The reason for the above phenomenon is precisely that the government often participates in disaster relief; residents expect to receive its benefits. Hence, they may confuse insurance liability with social responsibility, which reduces their motivation to purchase disaster insurance. The willingness, behavior, and influencing factors of purchasing natural disaster insurance have always been a focus of academic research [41-43]. Existing studies have mostly considered residents' personal characteristics, their families' socioeconomic characteristics, and government charity risk and have analyzed their correlations with insurance purchasing. For example, Dumm et al. [44] found that residents with a better understanding of the characteristics of natural disasters feel a more urgent need for insurance, and the occurrence of a disaster will greatly enhance residents' demand for insurance [44,45]. Zhu [46] found that residents' background cognition of earthquake risk was correlated with their insurance purchasing behavior. In fact, this behavior of residents or farmers buying natural disaster insurance essentially involves a consumer purchasing a commodity, and factors such as consumer income, recognition of goods, and trust in goods may all affect consumers' final purchase behavior [47]. However, few scholars have studied disaster insurance purchasing behavior and its influencing factors from this perspective. This is because, in traditional transactions, consumers can identify the quality of goods by what they see, touch, and feel when they use them. However, insurance products are purchased in advance in an environment involving distrust factors and high perceived risk [48]. Therefore, when purchasing such goods, consumers will pay attention to the factor of trust. Essentially, trust is a type of psychological expectation involved in interpersonal communication [49]. It can be divided into public trust and interpersonal trust [50]. Among them, governmental trust and collective trust are types of public trust which are established on the basis of law, politics, and other factors [51]. Government trust includes residents' psychological expectations and belief that the government will support their interests, while collective trust involves residents' expectations, dependence, and attributions related to local groups [52]. Generally speaking, the higher is the credibility of the local government, the stronger is its appeal and the more active residents are in participating in public policies [53]. Correspondingly, interpersonal trust is based on the relationships between people $[54,55]$. 
Although some scholars have realized the importance of trust in insurance purchasing, there are relatively few empirical studies on the relationship between trust and insurance in general. In the few that exist, there are some deficiencies. On the one hand, although some scholars have focused on the correlation between trust and insurance purchasing, most have considered new agricultural insurance and general commercial insurance rather than natural disaster insurance. For example, Huo et al. [49] found that under the influence of a "trust-cooperation" mechanism, trust had a significant positive influence on farmers' New Rural Social Pension Insurance (NRSP) purchasing behavior. Ding et al. found that only social trust level affected rural residents' purchasing of NRSP [55]. In fact, disaster insurance, NRSP, and general commercial insurance have some differences. Disasters are characterized by low frequency and high consequence [56]. Hence, the role of trust in purchasing such insurance may be different from that in regular insurance. On the other hand, in these limited studies, scholars have mostly explored the trust-insurance purchasing correlation from the perspective of trust objects (such as the government, experts, media, family, and neighbors) and a single trust dimension [49,57]. These two common research perspectives usually influence each other, resulting in overlapping that may lead to one-sided empirical research results. In addition, scholars mostly use conventional models, such as logit, OLS, and probit to study insurance purchasing behavior and its influences [58-60]. Although these methods have their merits, problems such as multiple influencing factors, complex research types, and multiple linear correlations in practical research increase the difficulty of analysis.

To sum up, existing studies have the following deficiencies: First, generally speaking, there are few empirical studies focusing on the relationship between trust and residents' insurance purchasing. Second, the ones that do have considered new agricultural insurance and general commercial insurance, and none have involved natural disaster insurance. Third, in these limited empirical studies, the research perspective has mostly been from the trust object or single trust dimension, and the conclusions may be biased. Fourth, logit, OLS, and probit models are the most used research methods and have difficulty in analyzing the interactions among multiple variables. Based on this, on the basis of the technology acceptance model (TAM), this paper divides trust into three dimensions: authority trust, collective trust, and relationship trust. We build a theoretical analysis framework for the factors of trust and natural disaster insurance purchasing behavior. Based on survey data from 327 households in the regions of the Wenchuan and Lushan earthquakes of Sichuan Province, China, the PLS-SEM method was used to explore the correlation between trust in different dimensions and the purchase of natural disaster insurance by farmers. The results provide a reference for the formulation and improvement of a natural disaster insurance policy in disaster-threatened areas based on theory and empirical evidence.

\section{Materials and Methods}

\subsection{Research Area}

Sichuan Province is located in southwestern China, and $97.46 \%$ of the area comprises hills, mountains, and plateaus. In addition to earthquake disasters, it has landslides, debris flows, and other secondary disasters. From 2005 to 2018, 144 earthquakes and 18,518 geological disasters, such as landslides and mudslides, occurred in Sichuan, causing 1390 casualties and a direct economic loss of RMB 8 billion [14]. Among them, the Wenchuan earthquake on 12 May 2008 (magnitude 8 on the Richter scale) and the Lushan earthquake on 20 April 2013 (magnitude 7) caused huge casualties and economic losses to local residents. Considering the non-negligible impact of earthquake disasters in a multi-disaster-threatened environment, this paper selected mountainous areas stricken by the Wenchuan and Lushan earthquakes as the study areas.

\subsection{Data Sources}

The data used in this paper came mainly from a questionnaire survey conducted by the research group in the worst-hit areas of the Wenchuan and Lushan earthquakes in August 
2019. The research examined the sustainable livelihoods of farmers, disaster risk perceptions, disaster avoidance behavior responses, and the construction of village resilience disaster prevention systems [61-63]. To ensure the representativeness of the survey, stratified equal probability random sampling was adopted to determine the survey samples.

In selecting sample districts (Figure 1), there were two main considerations: First, the four sample districts and counties should be from the worst-hit areas of the Wenchuan and Lushan earthquakes (these two major earthquakes each involved two districts and counties). Second, there is a significant difference in the economic development levels of the two sample counties involved in each major earthquake. Based on the above considerations, Beichuan County and Pengzhou City were selected as sample counties from 10 counties in the worst-hit areas of the Wenchuan earthquake. Baoxing County and Lushan County were selected from six counties in the worst-hit areas of the Lushan earthquake. After selecting the sample districts and counties, according to their differences in economic development level, the distances from the center of the districts to the counties, and the situation of severe disasters (especially the numbers of threatened people), two sample towns were randomly selected from each sample district and county-a total of eight towns. The third consideration was the selection of sample villages. After the determination of the sample towns, the villages in each were divided into two categories according to the number of threatened people, differences in economic development level, and the distance from the township center. Then, 1 village from each category was randomly selected as the sample village to obtain 16 villages. Finally, the sample farmers were determined. After the sample villages were determined, the frontline team members obtained lists of resident farmers from the village cadres and the following methods to determine the sample farmers. According to the total number of households in the village, the number of households threatened by secondary geological disasters, such as landslides and mudslides, and the level of economic development of the households, 20-23 households were selected from each sample village through a random number table. The sample households were ultimately 327, accounting for landslides and mudslides and other secondary geological disasters threatening $28.56 \%$ of households. Since the sample farmers we surveyed were generated through random number tables, and China's rural areas have relatively high homogeneity, our sample was still very representative of the sample villages (at least covering different levels of economic development: good, medium, and poor farmers, including farmers of varying degrees threatened by geological disasters). Since there were 13 people in the research team (including 1 team leader), our preliminary estimate was that the sample size was 24 households in a village. However, it was limited by actual conditions (limited funds, scattered rural households in mountainous areas, and the relatively high time cost of household surveys), so we only collected 20-23 households in each village, and 327 sample households accounted for $85.15 \%$ of the expected target households. At the same time, because the investigators were systematically trained masters and undergraduates, and they were led by the village cadres to enter the farmers' homes to do one-on-one surveys, our questionnaire was 100\% efficient. 

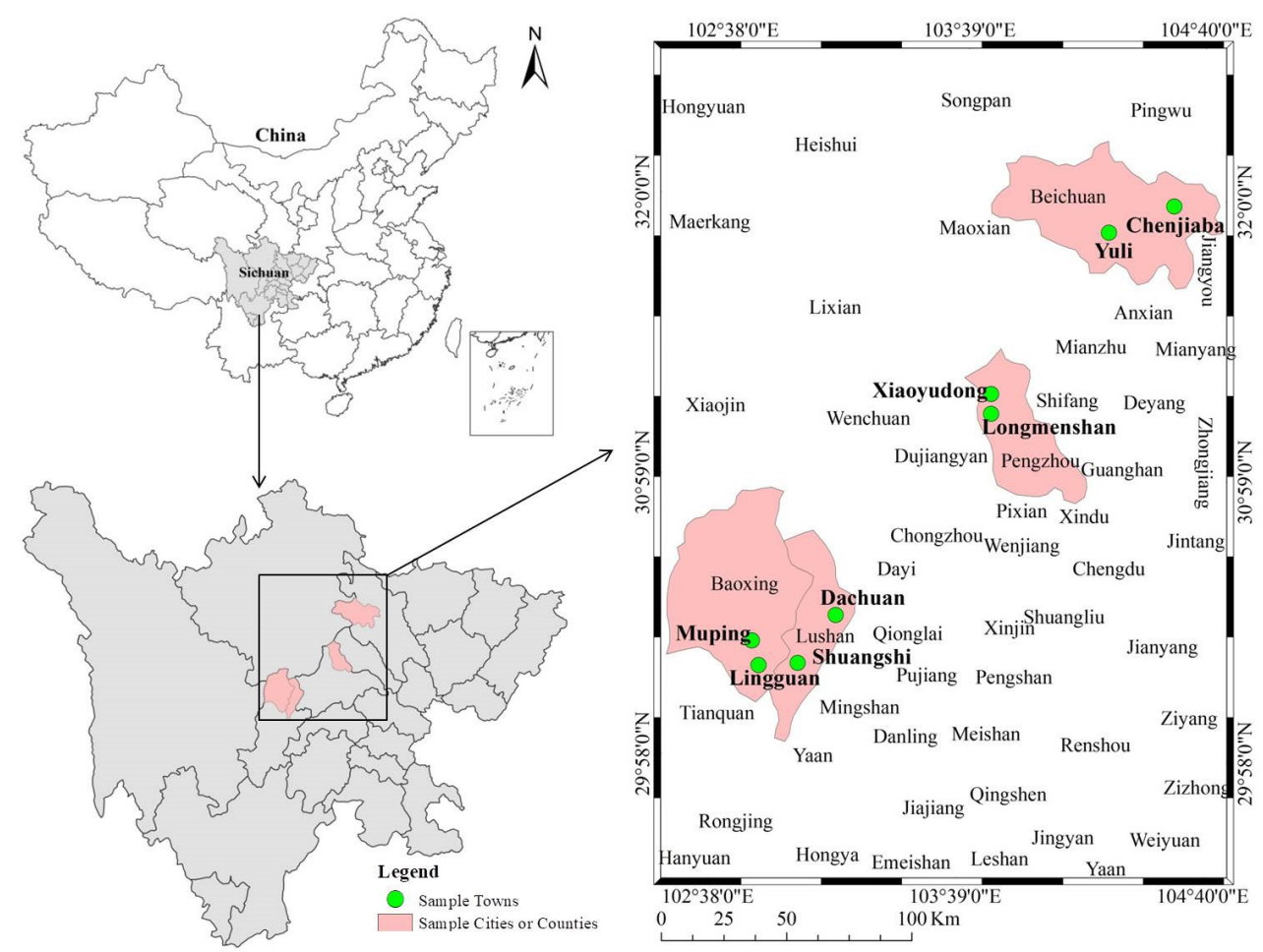

Figure 1. Location map of sample counties and towns.

\subsection{Theoretical Analysis and Research Hypotheses}

As mentioned above, trust is a type of psychological expectation involved in interpersonal communication [64]. At the same time, Chinese society is traditionally an "acquaintance society", and trust in this environment often involves low interaction with the outside world. People clearly classify themselves and outsiders based on mutual understanding through the scope of trust, which is specifically manifested as giving decreasing degrees of trust to relatives, acquaintances, and strangers, in that order. Once the category of blood relationship is broken, it is difficult to expand trust at every step $[65,66]$. Based on this, this paper divides trust into three dimensions: authority trust, collective trust, and relationship trust. It then comprehensively considers the nature of "buying behavior" and the purpose of studying the factors affecting insurance purchasing. Considering that the TAM model is a model of attitude intention behavior, it is often used in combination with other models to study consumers' purchasing behavior $[57,67,68]$. Therefore, on the basis of the TAM model and in combination with the system of trust dimensions, this paper assumes that the direct influences between the three trust dimensions and farmers' purchasing of natural disaster insurance are as follows:

Hypothesis 1. Authority trust has a direct and positive impact on farmers' natural disaster insurance purchasing behavior.

Hypothesis 2. Authority trust has a direct and positive impact on collective trust.

Hypothesis 3. Authority trust has a direct and positive impact on relationship trust.

Hypothesis 4. Collective trust has a direct and positive impact on relationship trust.

Hypothesis 5. Collective trust has a direct and positive impact on farmers' natural disaster insurance purchasing behavior.

Hypothesis 6. Relationship trust has a direct impact on farmers' natural disaster insurance purchasing behavior. 
In terms of the relationships between variables, if $X$ influences $Y$ through variable $M$, then $M$ is called an intermediary variable and is said to have an intermediary effect [69]. In fact, farmers' own purchasing behavior is mostly influenced by the psychological expectation of trust, which is called ripple effect [70]. However, due to the differences in trust objects and trust degrees, farmers are affected differently. In theory, authority trust and collective trust can indirectly affect farmers' natural disaster insurance purchasing behavior by influencing relationship trust. Therefore, the indirect impact path between trust and farmers' insurance purchasing is assumed as follows:

Hypothesis 7. Authority trust indirectly and positively influences farmers' natural disaster insurance purchasing by affecting collective trust; the action path is composed of the direct influence paths $\mathrm{H} 2$ and $\mathrm{H} 5$.

Hypothesis 8. Authority trust indirectly and positively influences farmers' natural disaster insurance purchasing by influencing relationship trust; the action path consists of the direct influencing paths $\mathrm{H} 3$ and $\mathrm{H} 6$.

Hypothesis 9. Authority trust indirectly and positively influences farmers' natural disaster insurance purchasing by affecting collective trust and then relationship trust; the effect path is composed of the direct influencing paths $\mathrm{H2}, \mathrm{H} 4$, and $\mathrm{H} 6$.

Hypothesis 10. Collective trust indirectly and positively influences farmers' purchasing of natural disaster insurance by influencing relationship trust; the effect path is composed of the direct influence paths $\mathrm{H} 4$ and $\mathrm{H} 6$.

The specific hypothetical paths are shown in Figure 2:

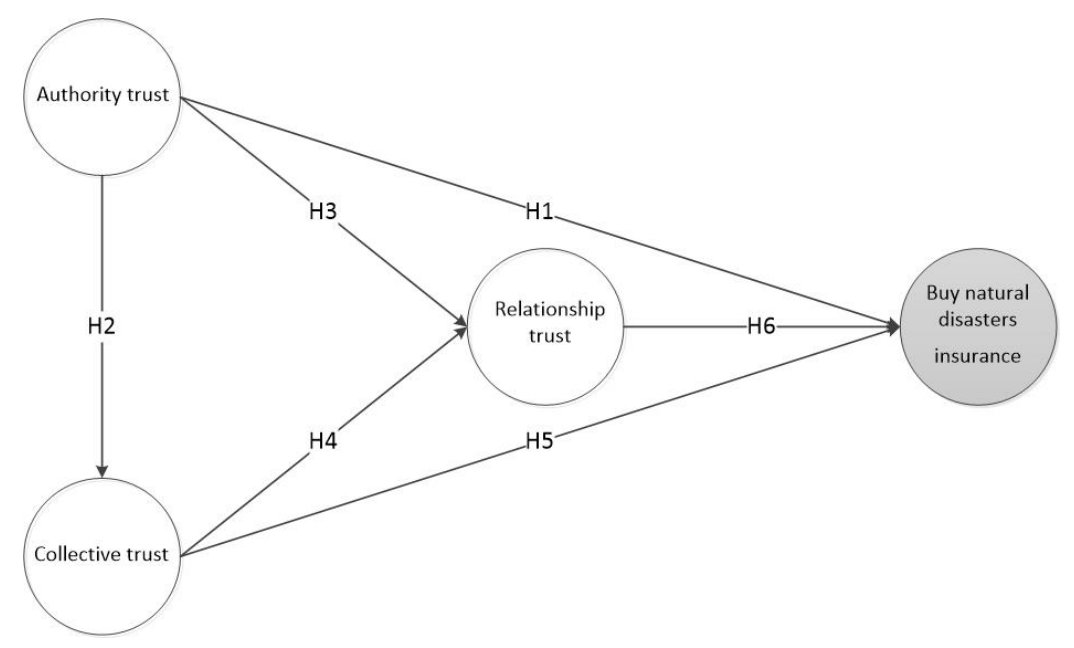

Figure 2. Examining the hypothetical path.

\subsection{Variables, Model, and Methods}

\subsubsection{Selection and Definition of Model Variables}

The aim of this paper is to reveal the effect of trust on farmers' purchasing of natural disaster insurance. The dependent variable is whether farmers buy natural disaster insurance, and the core independent variable is trust. According to the related theories of trust, this study further divides trust into authority trust, collective trust, and relationship trust. Among them, authority trust is measured by the respondents' and villagers' trust in the local government and the government's trust in disaster judgment, and entries are measured using Likert 5 Scale. Collective trust is measured by the villagers' trust in village cadres to communicate and solve problems, and in the village to convey collective information, and entries are measured using 5-point Likert scale. Relationship trust is measured by the residents' degree of trust in others in the village (neighbors, village cadres, etc.), family members, relatives, and friends in relation to disaster judgment, and entries are 
measured using 5-point Likert scale. At the same time, to further reveal the heterogeneous effects of trust on farmers' disaster insurance purchasing behavior, indicators representing residents' personal characteristics, risk perception, and risk preference were added as control variables [71-74]. The specific variables, dimensions, entry codes, measure entries, and descriptions are detailed in Table 1.

Table 1. Study variable setting and data description.

\begin{tabular}{|c|c|c|c|}
\hline Variable & Dimensionality & Entry Code & Entry \\
\hline Dependent variable & Purchasing behavior & $\mathrm{Y}$ & Are residents insured against natural disasters? ${ }^{\text {a }}$ \\
\hline \multirow{8}{*}{ Independent variables } & \multirow{3}{*}{ Authority trust } & A1 & $\begin{array}{l}\text { Do you find the government's assessment of the disaster } \\
\text { credible? }{ }^{b}\end{array}$ \\
\hline & & $\mathrm{A} 2$ & $\begin{array}{c}\text { People in the village have great faith in the government's } \\
\text { decisions? }{ }^{b}\end{array}$ \\
\hline & & $\mathrm{A} 3$ & In general, your level of trust in government? ${ }^{b}$ \\
\hline & \multirow{2}{*}{ Collective trust } & $\mathrm{C} 1$ & $\begin{array}{l}\text { What problem does the village have that everybody can } \\
\text { communicate with the village cadre and deal with? } \mathrm{b}\end{array}$ \\
\hline & & $\mathrm{C} 2$ & $\begin{array}{l}\text { The village tells relevant information to the villagers through } \\
\text { telephone/broadcast/cadre communication. } b\end{array}$ \\
\hline & \multirow{3}{*}{ Relationship trust } & R1 & Do you find the judgments of others in the village credible? $b$ \\
\hline & & $\mathrm{R} 2$ & In general, how much trust do you have in your family? ${ }^{b}$ \\
\hline & & R3 & In general, how much do you trust your friends and family? $b$ \\
\hline \multirow{6}{*}{ Control variables } & \multirow{2}{*}{$\begin{array}{c}\text { Personal } \\
\text { characteristics }\end{array}$} & P1 & How old are you? \\
\hline & & $\mathrm{P} 2$ & The per capita annual cash income of your family (USD). \\
\hline & \multirow[b]{2}{*}{ Risk perception } & S1 & Do you think your family lives in a disaster zone? ${ }^{a}$ \\
\hline & & S2 & $\begin{array}{l}\text { Overall, how serious do you think are the disasters you have } \\
\text { experienced? }\end{array}$ \\
\hline & \multirow{2}{*}{ Risk preference } & D1 & $\begin{array}{c}\text { Does your family buy any other insurance besides } \\
\text { endowment insurance? }\end{array}$ \\
\hline & & D2 & $\begin{array}{c}\text { Do you want to take some precautions for disaster prevention } \\
\text { and mitigation? }\end{array}$ \\
\hline
\end{tabular}

Note: ${ }^{\mathrm{a}}$ score $(0=$ no, $1=$ yes $) ;{ }^{\mathrm{b}}$ 5-point Likert scale, where 1 means strongly disagree and 5 means strongly agree.

\subsubsection{The Models}

According to the literature review and research hypotheses, farmers' purchasing of natural disaster insurance is a type of purchasing behavior. The TAM model is a kind of attitude intention behavior model that is suitable for studying consumers' purchase behavior and its influences. Therefore, this study intends to adopt a TAM model as the basic model framework to study trust and farmers' disaster insurance purchasing behavior and its influencing factors. Because there is a relatively complex relationship between several dimensions of trust and whether farmers buy natural disaster insurance, PLS-SEM analysis is adopted. This method does not need to assume the probability distributions of the observed variables and errors. It is often used to estimate complex models containing multiple variables and multiple influence paths [75]. Based on this, this study takes a TAM model as the basic model framework and combines it with the PLS-SEM analysis method to systematically explore the correlation between trust and farmers' purchasing of natural disaster insurance. See Figure 3 for the specific model construct. 


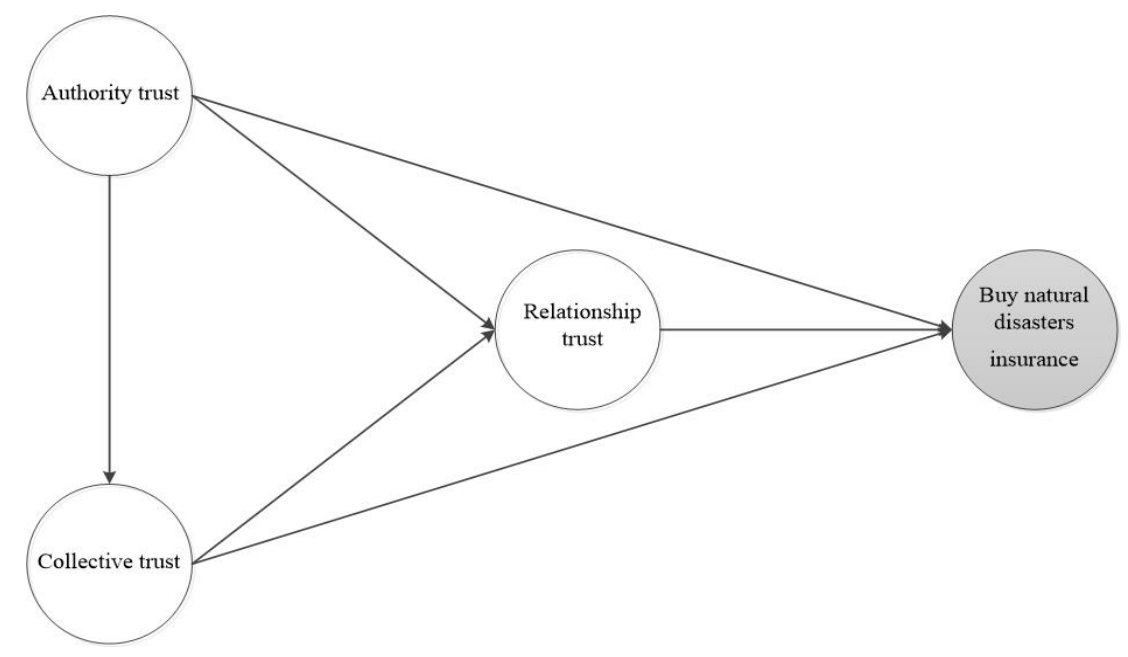

Figure 3. Model construction.

\section{Results}

\subsection{Model Verification}

Henseler pointed out that if a model does not pass the test of reliability and validity, then the results will be meaningless [76]. Therefore, before the specific analysis, the reliability and validity of each dimension of the model comprising the core variables were tested. As can be seen from Table 2, the Cronbach's $\alpha$ values of all the dimensions of the core variables are all $>0.6$, the composite reliability $(\mathrm{CR})$ values are all $>0.8$, and the average (AVE) values are all $>0.5$, indicating that the research-designed entries have good reliability. At the same time, the factor loadings of all the measured entries are $>0.7$, which indicates that they have good validity. The variance inflation factor (VIF) values of all the dimensions are $<3$, indicating that there is no serious multicollinearity problem among the core variables. In addition, the SRMR of this paper is 0.088 , which is lower than the upper limit of 0.100 , indicating that there is no hypothesis error in this study. The values of D_G and D_ULS are 0.166 and 0.351 , respectively, both of which are less than the upper limit of the $99 \%$ confidence interval, indicating that the model in this study passed the fitness test.

Table 2. Validity test of variables.

\begin{tabular}{|c|c|c|c|c|c|c|c|}
\hline Variable & Dimensionality & Entry Code & Outer Loading & Cronbach's $\alpha$ & CR & AVE & VIF \\
\hline \multirow{3}{*}{$\begin{array}{c}\text { Independent } \\
\text { variable }\end{array}$} & Authority trust & $\begin{array}{l}\text { A1 } \\
\text { A2 } \\
\text { A3 }\end{array}$ & $\begin{array}{l}0.788 \\
0.850 \\
0.726\end{array}$ & 0.707 & 0.832 & 0.623 & 1.417 \\
\hline & Collective trust & $\begin{array}{l}\mathrm{C} 1 \\
\mathrm{C} 2\end{array}$ & $\begin{array}{l}0.861 \\
0.872\end{array}$ & 0.668 & 0.857 & 0.750 & 2.060 \\
\hline & Relationship trust & $\begin{array}{l}\text { R1 } \\
\text { R2 } \\
\text { R3 }\end{array}$ & $\begin{array}{l}0.710 \\
0.852 \\
0.855\end{array}$ & 0.740 & 0.849 & 0.654 & 1.885 \\
\hline $\begin{array}{c}\text { Dependent } \\
\text { variable }\end{array}$ & & $\mathrm{Y}$ & 1.000 & 1.000 & & & \\
\hline
\end{tabular}

\subsection{Model Results}

The output results of the model are shown in Table 3. Six paths are significant; among them, the four paths of direct positive significance are: $\mathrm{H} 2$ : authority trust $\rightarrow$ collective trust, H3: authority trust $\rightarrow$ relationship trust, H4: collective trust $\rightarrow$ relationship trust, and H6: relationship trust $\rightarrow$ whether to buy natural disaster insurance. The two indirect positive significant paths are: H9: authority trust $\rightarrow$ collective trust $\rightarrow$ relationship trust $\rightarrow$ whether to buy natural disaster insurance, and H10: collective trust $\rightarrow$ relationship trust $\rightarrow$ whether to 
buy natural disaster insurance. In addition, H1: authority trust $\rightarrow$ whether to buy natural disaster insurance, H5: collective trust $\rightarrow$ whether to buy natural disaster insurance, H7: authority trust $\rightarrow$ collective trust $\rightarrow$ whether to buy natural disaster insurance, and H8: authority trust $\rightarrow$ relationship trust $\rightarrow$ whether to buy natural disaster insurance are not significant.

Table 3. Model results.

\begin{tabular}{|c|c|c|c|c|}
\hline Assumed Influence Path & Path Coefficient & T Value & $p$-Value & Inspection Result \\
\hline $\begin{array}{c}\text { H1: authority trust } \rightarrow \text { whether to buy natural } \\
\text { disaster insurance }\end{array}$ & 0.088 & 1.485 & 0.138 & No \\
\hline $\mathrm{H} 2:$ authority trust $\rightarrow$ collective trust & $0.527 * * *$ & 11.227 & 0.000 & Yes \\
\hline H3: authority trust $\rightarrow$ relationship trust & $0.142 * *$ & 2.680 & 0.007 & Yes \\
\hline H4: collective trust $\rightarrow$ relationship trust & $0.601 * * *$ & 11.625 & 0.000 & Yes \\
\hline $\begin{array}{c}\text { H5: collective trust } \rightarrow \text { whether to buy natural } \\
\text { disaster insurance }\end{array}$ & 0.021 & 0.304 & 0.761 & No \\
\hline $\begin{array}{l}\text { H6: relationship trust } \rightarrow \text { whether to buy natural } \\
\text { disaster insurance }\end{array}$ & $0.191 * *$ & 2.828 & 0.005 & Yes \\
\hline $\begin{array}{l}\text { H7: authority trust } \rightarrow \text { collective trust } \rightarrow \text { whether } \\
\text { to buy natural disaster insurance } \\
\text { H8: authority trust } \rightarrow \text { relationship }\end{array}$ & 0.012 & 0.301 & 0.763 & No \\
\hline $\begin{array}{c}\text { trust } \rightarrow \text { whether to buy natural disaster } \\
\text { insurance are not significant }\end{array}$ & 0.027 & 1.927 & 0.154 & No \\
\hline H9: authority trust $\rightarrow$ collective & & & & \\
\hline $\begin{array}{c}\text { trust } \rightarrow \text { relationship trust } \rightarrow \text { whether to buy } \\
\text { natural disaster insurance }\end{array}$ & $0.061^{* *}$ & 2.583 & 0.010 & Yes \\
\hline $\begin{array}{c}\text { H10: collective trust } \rightarrow \text { relationship } \\
\text { trust } \rightarrow \text { whether to buy natural disaster } \\
\text { insurance }\end{array}$ & $0.115^{* *}$ & 2.696 & 0.007 & Yes \\
\hline
\end{tabular}

Note: ${ }^{* *}$ means $p<0.05$, and ${ }^{* *}$ means $p<0.001$.

As can be seen from Table 3, among the direct effects, only relationship trust is positively and significantly correlated with whether farmers buy natural disaster insurance or not, and the path coefficient is 0.191. A possible explanation for this result is that China is traditionally an acquaintance society, and the social behavior of peasant households shows a typical "ripple effect" (Tan et al., 2021). Relatives and friends, as direct contacts, can drive and influence the behavioral decisions of farmers in real time. At the same time, people have a herd mentality. Once their relatives and friends have certain related consumption behaviors, most farmers will be naturally driven to consume similarly if economic conditions permit.

From the perspective of the three significant paths affecting farmers' purchasing behavior, first, the path coefficient of H10 is 0.115 , which is lower than that of H6 (0.191). This shows that the collective, as an authoritative and close "hub", not only conveys the policies and instructions of the authoritative government from the upper level downward but also expresses the difficulties and demands of farmers up the bureaucratic hierarchy. In obvious correspondence with the two paths of $\mathrm{H} 2$ and $\mathrm{H} 4$, although the collective cannot directly affect farmers' natural disaster insurance buying behavior, it can indirectly affect it by influencing their living conditions, by conveying the benefits of natural disaster insurance, and by influencing others in the farmers' network. Second, by comparing the insignificant $\mathrm{H} 7$ and $\mathrm{H} 8$ and the significant $\mathrm{H} 9$ hypotheses, it can be seen that only through the collective "hub" can the authorities indirectly affect the relationship trust of farmers, which will have a significant impact on their disaster insurance purchasing behavior. Note that this process generates a "dielectric"-like loss, which may explain why the path coefficients of $\mathrm{H} 9$ are lower than those of $\mathrm{H} 10$ and $\mathrm{H} 6$, which also correspond to the path coefficients of two notable paths, $\mathrm{H} 2$ and H3. Finally, the path coefficients of both $\mathrm{H} 9$ and $\mathrm{H} 10$ are lower than that of H6. In the absence of knowledge about disaster insurance provided by the government and village collective, farmers generally make decisions based on information provided by relatives and friends. To get the attention 
of others or express their feelings, these people often add personal emotions and wills to such information intentionally or unintentionally. In this context, the disaster information obtained by farmers themselves tends to be exaggerated. In addition, Chinese people are very conscious of their own "face" (especially honor and morality) and can be easily influenced by other farmers to buy natural disaster insurance.

It is worth noting that, echoing the significant path $\mathrm{H6}$, among the three paths that significantly affect farmers' disaster insurance purchasing behavior, the direct influence that ultimately determines whether farmers will buy natural disaster insurance is relational trust. This shows that no matter how local governments, other authorities, and village collectives guide and encourage local farmers to buy disaster insurance, policy making may need to focus more on the trust relationships between farmers.

\subsection{Heterogeneity Analysis}

To further reveal the heterogeneous effects of trust on farmers' disaster insurance purchasing behavior, indicators representing farmers' personal characteristics, risk perceptions, and risk preferences were added as control variables. Group analysis was conducted on the basis of satisfying reliability and validity, and the specific group division and path coefficients of the H6, H9, and H10 significant paths are shown in Figure 4 [77,78]. The specific analysis is as follows.
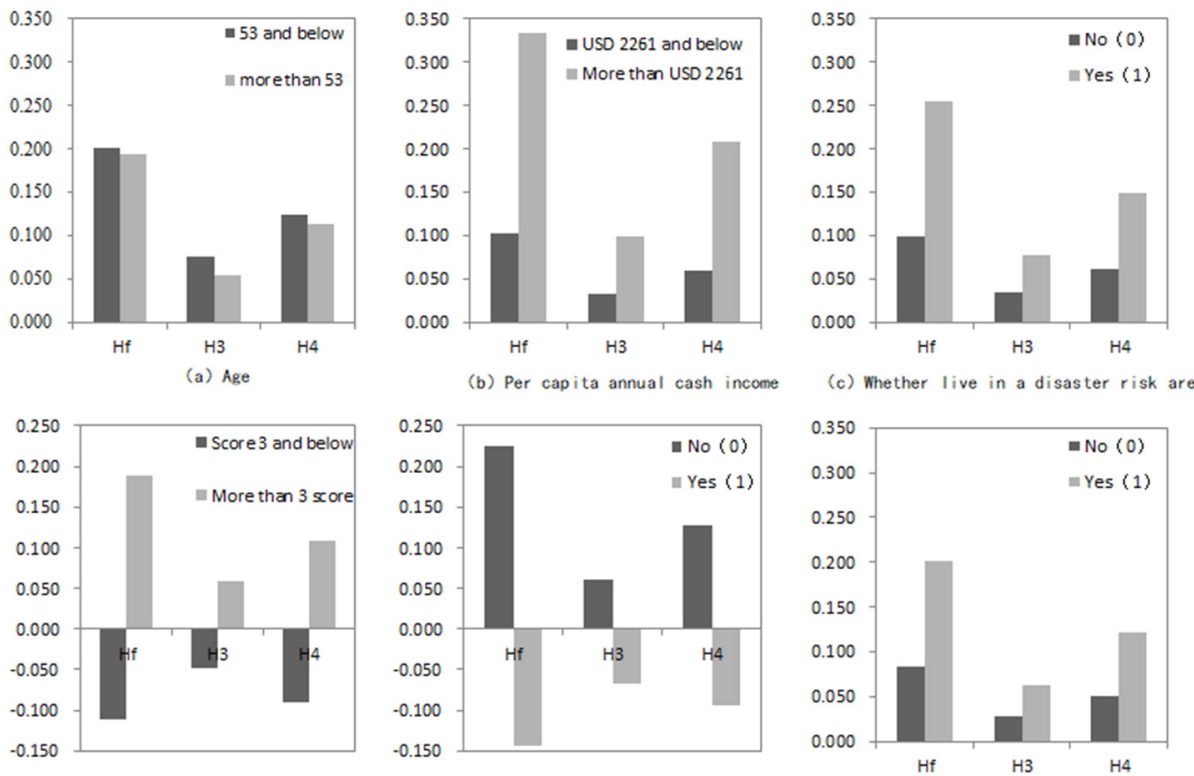

(d) The severity of disaster experienced

(e) Have you purchased any other insurance

(f) Whether to take prevent ive measures

Figure 4. Heterogeneity analysis results.

In terms of personal characteristics, farmers under the age of 53 years and with an annual per capita income of more than USD 2261 are more willing to buy disaster insurance. One possible explanation is that the younger the farmers are, the more receptive they are to new things and the faster is the spread of new ideas among peers. Conversely, the older people are, the richer is their life experience, and the more indifferent they are to life and death, and the lower is their need for security. At the same time, with the development of the social economy and improvement in farmers' income level, purchasing power is enhanced. After meeting their basic physiological needs, farmers seek a higher level of security needs, that is, a stable and safe living environment, personal safety, and property protection. Such inhabitants must be protected from fear and anxiety in order to lead orderly lives.

In terms of risk perception, people who believe that disasters are serious or very serious and people who live in areas threatened by disasters are more likely to buy disaster insurance. This is because such farmers have strong risk perception and a rapidly increasing 
demand for personal safety and property protection, which will significantly improve their own disaster insurance purchasing behavior.

In terms of risk preference, farmers who have not bought other insurance and want to take measures to avoid and mitigate disasters and follow the guidance and trust of authorities (such as the government and village collective) are more inclined to buy disaster insurance. This is because farmers who have already bought other commercial insurance to protect their personal and property safety are reluctant to buy separate disaster insurance, which will increase the expense and burden on their families. In contrast, farmers who have not purchased other insurance are more likely to follow the guidance of authorities (such as the government and the collective), improve their awareness of disaster prevention, and increase their collective trust and authority trust, and thus, are more likely to purchase disaster insurance. Farmers who have made preparations for disaster mitigation are typically risk averse and may be more willing to purchase disaster insurance under the guidance of authorities (such as the government and the collective) than to bear all the risks themselves.

\section{Discussion}

Through empirical analysis and discussion of the results, this paper draws the following main conclusions:

1. Among the three trust variables of authority trust, collective trust, and relational trust considered in this paper, only relational trust had a direct, positive, and significant impact on disaster insurance purchasing behavior. At the same time, although collective trust cannot directly affect purchasing behavior, it can directly and positively affect residents' relational trust and then indirectly affect purchasing behavior, producing a positive and significant correlation with an indirect effect. Authority trust can directly and positively affect residents' collective trust and then indirectly affect relationship trust and, finally, purchasing behavior, producing a positive and significant correlation.

2. From the heterogeneity analysis, it can be seen that the younger is the age, the higher is the per capita annual cash income. Residents of disaster areas who have experienced severe natural disasters and have not purchased other commercial insurance and are risk averse are more likely to take measures to protect their personal and property safety.

Based on the above analysis, several policy implications can be drawn: First, importance should be attached to relational trust. Disaster risk management policies can be taken as a starting point to influence residents by influencing their peers. Second, attention should be paid to the role of the collective "hub", increasing the manpower of the grassroots village collective; improving staff quality, office efficiency, and office quality; and enhancing residents' trust and dependence on the village collective. Third, the credibility of the government and other authorities and residents' affinity for them, so as to establish an honest and reliable image for local residents, enhances their sense of dependence and trust and brings people together.

Combined with the model results and conclusions of this article, this article puts forward the following policy recommendations: First, the Chinese government should vigorously promote policy-based natural disaster insurance and design a set of natural disaster insurance systems that are more suitable for Chinese farmers by referring to the results of current insurance pilots in Yunnan and Sichuan. Second, the Chinese government should design targeted natural disaster insurance types based on field surveys conducted by teams of universities and enterprises, such as Yunnan's earthquake housing insurance. Finally, the government bears a certain percentage of insurance premiums and issues policies to local governments, and village leaders take the lead in vigorously promoting, through government underwriting, collective propaganda and mutual influence of farmers to promote the implementation of natural disaster insurance in disaster areas in China.

Finally, the research limitations of this article include the following aspects: First of all, this article focuses on research on the influence of the element of "trust" on the 
purchase of insurance by farmers. Although the control variables in the model involve the personal characteristics, risk perception, and risk preference of local residents, other relevant research studies mentioned in risk communication and property losses, such as specific disaster content, are not involved. Second, due to differences in correlation measurements and influencing factors of different types and variables, future research will deepen the understanding of the correlation between farmers and natural disasters, such as earthquakes, and explore and construct a more scientific and reasonable correlation-type system. Finally, in the future, this research will further increase farmers' trust in social institutions, such as insurance companies and the media, in terms of farmers' trust in the government and other authoritative institutions and grassroots collectives. In this way, a multiangle and multiagent research method is used to test the trust relevance of different subjects and their differences.

Author Contributions: Conceptualization, X.B. and D.X.; methodology, F.Z. and X.D.; software, X.D.; formal analysis, X.B. and F.Z.; investigation, D.X.; writing—original draft preparation, X.B. and D.X.; writing-review and editing, X.B. and D.X.; supervision, D.X.; funding acquisition, D.X. All authors have read and agreed to the published version of the manuscript.

Funding: This research was funded by National Natural Science Foundation of China (41801221), Special Program for Cultivating Excellent Young Talents under the Dual Support Plan of Sichuan Agricultural University, Undergraduate research interest cultivation program in 2021 of Sichuan agricultural university $(2021489 ; 2021488)$.

Institutional Review Board Statement: Not applicable.

Informed Consent Statement: Not applicable.

Acknowledgments: We gratefully acknowledge financial support from National Natural Science Foundation of China (41801221), Special Program for Cultivating Excellent Young Talents under the Dual Support Plan of Sichuan Agricultural University, Undergraduate research interest cultivation program in 2021 of Sichuan agricultural university $(2021489 ; 2021488)$. The authors also extend great gratitude to the anonymous reviewers and editors for their helpful review and critical comments.

Conflicts of Interest: The authors declare that they have no conflicts of interest. This article does not contain any studies with human participants or animals performed by any of the authors. Informed consent was obtained from all the individual participants included in the study.

\section{References}

1. Xu, D.; Peng, L.; Liu, S.; Wang, X. Influences of risk perception and sense of place on landslide disaster preparedness in southwestern China. Int. J. Disaster Risk Sci. 2018, 9, 167-180. [CrossRef]

2. Peng, L.; Lin, L.; Liu, S.; Xu, D. Interaction between risk perception and sense of place in disaster-prone mountain areas: A case study in China's Three Gorges Reservoir Area. Nat. Hazards 2017, 85, 777-792. [CrossRef]

3. Comfort, L.K.; Zhang, H. Operational networks: Adaptation to extreme events in China. Risk Anal. 2020, 4, 981-1000. [CrossRef] [PubMed]

4. McAneney, J.; McAneney, D.; Musulin, R.; Walker, G.; Crompton, R. Government-sponsored natural disaster insurance pools: A view from down-under. Int. J. Disaster Risk Reduct. 2016, 15, 1-9. [CrossRef]

5. Rawluk, A.; Ford, R.M.; Neolaka, F.L.; Williams, K.J. Public values for integration in natural disaster management and planning: A case study from Victoria, Australia. J. Environ. Manag. 2017, 185, 11-20. [CrossRef] [PubMed]

6. Steffen, W.L. Global change and the earth system: A planet under pressure. EGS AGU EUG Jt. Assem. 2004, 8, 13-20. [CrossRef]

7. Peng, L.; Xu, D.; Wang, X. Vulnerability of rural household livelihood to climate variability and adaptive strategies in landslidethreatened western mountainous regions of the Three Gorges Reservoir Area, China. Clim. Dev. 2019, 11, 469-484. [CrossRef]

8. Xu, D.; Zhang, J.; Rasul, G.; Liu, S.; Xie, F.; Cao, M.; Liu, E. Household livelihood strategies and dependence on agriculture in the mountainous settlements in the three gorges reservoir area, China. Sustainability 2015, 7, 4850-4869. [CrossRef]

9. Xu, D.; Guo, S.; Xie, F.; Liu, S.; Cao, S. The impact of rural laborer migration and household structure on household land use arrangements in mountainous areas of Sichuan Province, China. Habitat Int. 2017, 70, 72-80. [CrossRef]

10. Guo, S.; Lin, L.; Liu, S.; Wei, Y.; Xu, D.; Li, Q.; Su, S. Interactions between sustainable livelihood of rural household and agricultural land transfer in the mountainous and hilly regions of Sichuan, China. Sustain. Dev. 2019, 27, 725-742. [CrossRef]

11. Xu, D.; Deng, X.; Guo, S.; Liu, S. Labor migration and farmland abandonment in rural China: Empirical results and policy implications. J. Environ. Manag. 2019, 232, 738-750. [CrossRef] 
12. Xu, D.D.; Deng, X.; Huang, K.; Liu, Y.; Yong, Z.; Liu, S. Relationships between labor migration and cropland abandonment in rural China from the perspective of village types. Land Use Policy 2019, 88, 104164. [CrossRef]

13. Deng, X.; Xu, D.; Zeng, M.; Qi, Y. Does early-life famine experience impact rural land transfer? Evidence from China. Land Use Policy 2019, 81, 58-67. [CrossRef]

14. Deng, X.; Xu, D.; Zeng, M.; Qi, Y. Does Internet use help reduce rural cropland abandonment? Evidence from China. Land Use Policy 2019, 89, 104243. [CrossRef]

15. Xu, D.; Peng, L.; Liu, S.; Su, C.; Wang, X.; Chen, T. Influences of migrant work income on the poverty vulnerability disaster threatened area: A case study of the Three Gorges Reservoir area, China. Int. J. Disaster Risk Reduct. 2017, 22, 62-70. [CrossRef]

16. Zeng, X.; Fu, Z.; Deng, X.; Xu, D. The Impact of Livelihood Risk on Farmers of Different Poverty Types: Based on the Study of Typical Areas in Sichuan Province. Agriculture 2021, 11, 768. [CrossRef]

17. Beniston, M. Climatic change in mountain regions: A review of possible impacts. In Climate Variability and Change in High Elevation Regions: Past, Present \& Future; Diaz, H.F., Ed.; Springer: Dordrecht, The Netherlands, 2003; pp. 5-31. [CrossRef]

18. Kappes, M.S.; Keiler, M.; Glade, T. From single-to multi-hazard risk analyses: A concept addressing emerging challenges. In Proceedings of the Mountain Risks: Bringing Science to Society: Proceedings of the Mountain Risks International Conference, Firenze, Italy, 24-26 November 2010.

19. Ying, B.; Fang, Y. Classification and spatial pattern of mountainous areas in China. J. Guizhou Norm. Univ. Nat. Sci. Ed. 2017, 35, 7-14.

20. Zimmermann, M. Managing debris flow risks. Mt. Res. Dev. 2004, 24, 19-23. [CrossRef]

21. Zimmermann, M.; Keiler, M. International frameworks for disaster risk reduction: Useful guidance for sustainable mountain development? Mt. Res. Dev. 2015, 35, 195-202. [CrossRef]

22. Wu, J.; He, X.; Li, Y.; Shi, P.; Ye, T.; Li, N. How earthquake-induced direct economic losses change with earthquake magnitude, asset value, residential building structural type and physical environment: An elasticity perspective. J. Environ. Manag. 2019, 231, 321-328. [CrossRef]

23. Zhou, W.; Guo, S.; Deng, X.; Xu, D. Livelihood resilience and strategies of rural residents of earthquake-threatened areas in Sichuan Province, China. Nat. Hazards 2021, 106, 255-275. [CrossRef] [PubMed]

24. Zhou, W.; Ma, Z.; Guo, S.; Deng, X.; Xu, D. Livelihood capital, evacuation and relocation willingness of residents in earthquakestricken areas of rural China. Saf. Sci. 2021, 141, 105350. [CrossRef]

25. Du, P.; Chen, J.; Chen, C.; Liu, Y.; Liu, J.; Wang, H.; Zhang, X. Environmental risk evaluation to minimize impacts within the area affected by the Wenchuan earthquake. Sci. Total Environ. 2012, 419, 16-24. [CrossRef] [PubMed]

26. Wang, C.Y.; Guo, J.; Kuo, M.F. The building of social resilience in Sichuan after the Wenchuan earthquake: A perspective of the socio-government interactions. Saf. Sci. 2020, 126, 104662. [CrossRef]

27. China Statistics Press. China Statistical Yearbook; National Bureau of Statistics of the People's Republic of China: Beijing, China, 2019.

28. Zeng, X.; Guo, S.; Deng, X.; Zhou, W.; Xu, D. Livelihood risk and adaptation strategies of farmers in earthquake hazard threatened areas: Evidence from Sichuan province, China. Int. J. Disaster Risk Reduct. 2021, 53, 101971. [CrossRef]

29. Ma, Z.; Guo, S.; Deng, X.; Xu, D. Community resilience and resident's disaster preparedness: Evidence from China's earthquakestricken areas. Nat. Hazards 2021, 108, 567-591. [CrossRef]

30. Qing, C.; Guo, S.; Deng, X.; Xu, D. Farmers' Disaster Preparedness and Quality of Life in Earthquake-prone Areas: The Mediating Role of Risk Perception. Int. J. Disaster Risk Reduct. 2021, 59, 102252. [CrossRef]

31. Yang, X.; Guo, S.; Deng, X.; Xu, D. Livelihood Adaptation of Rural Households under Livelihood Stress: Evidence from Sichuan Province, China. Agriculture 2021, 11, 506. [CrossRef]

32. Tversky, A.; Kahneman, D. Loss Aversion in Riskless Choice: A Reference-Dependent Model. Q. J. Econ. 1991, $106,1039-1061$. [CrossRef]

33. Crick, F.; Jenkins, K.; Surminski, S. Strengthening insurance partnerships in the face of climate change-insights from an agentbased model of flood insurance in the UK. Sci. Total Environ. 2018, 636, 192-204. [CrossRef]

34. Rumson, A.G.; Hallett, S.H. Innovations in the use of data facilitating insurance as a resilience mechanism for coastal flood risk. Sci Total Environ. 2019, 661, 598-612. [CrossRef] [PubMed]

35. Wang, M.; Liao, C.; Yang, S.; Zhao, W.; Liu, M.; Shi, P. Are people willing to buy natural disaster insurance in China? Risk awareness, insurance acceptance, and willingness to pay. Risk Anal. 2012, 32, 1717-1740. [CrossRef] [PubMed]

36. Yang, F.; Tan, J.; Peng, L. The effect of risk perception on the willingness to purchase hazard insurance-A case study in the Three Gorges Reservoir region, China. Int. J. Disaster Risk Reduct. 2020, 45, 101379. [CrossRef]

37. Zhuo, Y.L. A Catastrophe Insurance Pilot Implementation Effect Evaluation Research of Guangdong Province. Master's Thesis, Lanzhou University, Lanzhou, China, 2019. (In Chinese)

38. Peng, L.; Tan, J.; Lin, L.; Xu, D. Understanding sustainable disaster mitigation of stakeholder engagement: Risk perception, trust in public institutions, and disaster insurance. Agron. Sustain. Dev. 2019, 27, 885-897. [CrossRef]

39. Kunreuther, H. Preparing for the next natural disaster: Learning from Katrina. LDI Issue Brief 2006, 11, 1-4.

40. Wei, H.L.; Li, W.J. Risk analysis and insurance liability differentiation of major earthquakes in historical latitude. Comparative analysis of the securitization of life insurance. Insurance Stud. 2008, 9, 31-35. 
41. Antwi-Boasiako, B.A. It's beyond my control: The effect of locus of control orientation on disaster insurance adoption. Int. J. Disaster Risk Reduct. 2017, 22, 297-303. [CrossRef]

42. Ding, Y.H. Study on affordability of catastrophe insurance. Insur. Res. 2011, 10, 77-85.

43. Pan, L.; Zhong, C.P. Trustworthiness, Trust in Others and the Development of Insurance Industry: Evidence from China's Insurance Industry at the Provincial Level. Credit Rep. 2017, 5, 1-11.

44. Dumm, R.E.; Eckles, D.L.; Nyce, C.; Volkman-Wise, J. Demand for Catastrophe Insurance and the Representative Heuristic; Florida State University: Tallahassee, FL, USA, Under Review.

45. Kunreuther, H.; Pauly, M. Neglecting disaster: Why don't people insure against large losses? J. Risk Uncertain. 2004, 28 , 5-21. [CrossRef]

46. Zhu, W.; Chen, B.Z. Analysis on Influencing Factors of Catastrophe Insurance Demand of Chinese Residents-Taking Earthquake Risk as an Example. Insur. Res. 2015, 2, 14-23.

47. Zhang, L.; Chen, H.H.; Xu, F. Analysis of Rural Consumers' Online Purchase Behavior and Influencing Factors. J. China Agric. Univ. 2020, 25, 172-180.

48. Pan, Y.; Zhang, X.; Gao, L. Factors influencing consumers' purchase intention in online retail: Based on trust and perceived risk analysis. China Ind. Econ. 2010, 7, 115-124.

49. Wang, X.N. The Agricultural Catastrophe Insurance Purchase Intention and Influencing Factors of Study. Master's Thesis, Chinese Academy of Agricultural Sciences, Beijing, China, 2020.

50. Dussaillant, F.; Guzmán, E. Trust via disasters: The case of Chile's 2010 earthquake. Disasters 2014, 38, 808-832. [CrossRef] [PubMed]

51. Luhmann, N. Trust and Power; John Wiley \& Sons: Hoboken, NJ, USA, 2018.

52. He, K.; Zhang, J.B.; Tian, Y.; Feng, J.H. Analysis of farmers' agricultural low-carbon production behavior and its influencing factors: A case study of chemical fertilizer application and pesticide use. China Rural. Obs. 2015, 4, 61-70. (In Chinese)

53. Jiang, X.Q.; Chen, D.Q. Government trust and its theoretical research from the perspective of public management. Soc. Sci. J. 2006, 4, 41 .

54. Zhang, C.C.; Hu, Z.C. Government Trust and Social Public Policy Participation-Taking Grassroots Election Voting and Social Medical Insurance Participation as Examples; The University of Chicago Press: Chicago, IL, USA, 2016.

55. Huo, P.; Zhang, J.; Peng, C.; Cui, H. The impact of social interaction and trust on farmers' participation in the "new rural insurance"-An empirical analysis based on the survey data of CGSS2010. J. Agrotech. Econ. 2016, 6, 68-76.

56. Ding, C.M.; Wu, Y.J.; Qin, S.Y.; Liang, Z.Q. Social trust and implementation efficiency of public policy: Based on micro evidence of rural residents' participation in the new rural insurance system. Chin. Rural. Econ. 2019, 5, 109-123. (In Chinese)

57. Xu, D.; Liu, E.; Wang, X.; Tang, H.; Liu, S. Rural households' livelihood capital, risk perception, and willingness to purchase earthquake disaster insurance: Evidence from southwestern China. Int. J. Environ. Res. Public Health 2018, 15, 1319. [CrossRef] [PubMed]

58. Zhou, Z.G. The Earthquake Insurance Purchase Intention Research. Ph.D. Dissertation, Southwestern University of Finance and Economics, Chengdu, China, 2014.

59. Ghazanfar, S.; Qi-Wen, Z.; Abdullah, M.; Ahmed, J.; Khan, I.; Ahmad, Z. Factors Hindering Pakistani Farmers' Choices Towards Adoption of Crop Insurance. J. Northeast Agric. Univ. Engl. Ed. 2015, 22, 92-96. [CrossRef]

60. Wang, C. Research to the Influential Factors of Residents Geological Disaster Insurance Will. Master's Thesis, Lanzhou University, Lanzhou, China, 2017.

61. Xu, D.; Yong, Z.; Deng, X.; Liu, Y.; Huang, K.; Zhou, W.; Ma, Z. Financial Preparation, Disaster Experience, and Disaster Risk Perception of Rural Households in Earthquake-Stricken Areas: Evidence from the Wenchuan and Lushan Earthquakes in China's Sichuan Province. Int. J. Environ. Res. Public Health 2019, 16, 3345. [CrossRef]

62. Xu, D.; Liu, Y.; Deng, X.; Qing, C.; Zhuang, L.; Yong, Z.; Huang, K. Earthquake Disaster Risk Perception Process Model for Rural Households: A Pilot Study from Southwestern China. Int. J. Environ Res. Public Health 2019, 22, 4512. [CrossRef]

63. Zhuang, L.; He, J.; Yong, Z.; Deng, X.; Xu, D. Disaster information acquisition by residents of China's earthquake-stricken areas. Int. J. Disaster Risk Reduct. 2020, 51, 101908. [CrossRef]

64. Lo, A.Y. The role of social norms in climate adaptation: Mediating risk perception and flood insurance purchase. Glob. Environ. Chang. 2013, 23, 1249-1257. [CrossRef]

65. Chen, Y.L.; Ma, Y. Several Notes on Farmers' Credit and Risk Preference. Financ. Trade Econ. 2009, 1, 18-25.

66. Fei, X. Rural China; Shanghai People's Publishing House: Shanghai, China, 2019.

67. Davis, F.D. Perceived usefulness, perceived ease of use, and user acceptance of information technology. MIS Q. 1989, 319-340. [CrossRef]

68. Pavlou, P.A. Consumer acceptance of electronic commerce: Integrating trust and risk with the technology acceptance model. Int. J. Electron. Commer. 2003, 7, 101-134. [CrossRef]

69. Dai, K.; Chen, W.; Qiu, X. A study on the influencing factors of tourism experience sharing behavior in virtual communities: An improved PLS-SEM measurement based on TAM model. Math. Pract. Cogn. 2020, 6, 53-61.

70. Tan, J.; Zhou, K.; Peng, L.; Lin, L. The role of social networks in relocation induced by climate-related hazards: An empirical investigation in China. Clim. Dev. 2021, 1-12. [CrossRef] 
71. Xu, D.D.; Zhuang, L.M.; Deng, X.; Qing, C.; Yong, Z.L. Media Exposure, Disaster Experience, and Risk Perception of Rural Households in Earthquake-Stricken Areas: Evidence from Rural China. Int. J. Environ. Res. Public Health 2020, 17, 3246. [CrossRef]

72. Yong, Z.L.; Zhuang, L.M.; Liu, Y.; Deng, X.; Xu, D.D. Differences in the Disaster-Preparedness Behaviors of the General Public and Professionals: Evidence from Sichuan Province, China. Int. J. Environ. Res. Public Health 2020, 17, 5254. [CrossRef] [PubMed]

73. Xu, D.; Zhou, W.; Deng, X.; Ma, Z.; Yong, Z.; Qing, C. Information credibility, disaster risk perception and evacuation willingness of rural households in China. Nat. Hazards 2020, 103, 2865-2882. [CrossRef]

74. Xu, D.; Peng, L.; Su, C.; Liu, S.; Wang, X.; Chen, T. Influences of Mass Monitoring and Mass Prevention Systems on Peasant Households' Disaster Risk Perception in the Landslide-threatened Three Gorges Reservoir Area, China. Habitat Int. 2016, 58, 23-33. [CrossRef]

75. Yu, H.; Wang, M. Research on the influencing factors and action path of circular economy in iron and steel enterprises. Ind. Saf. Environ. Prot. 2016, 11, 98-102.

76. Henseler, J.; Hubona, G.; Ray, P.A. Using PLS path modeling in new technology research: Updated guidelines. Ind. Manag. Data Syst. 2016, 1, 2-20. [CrossRef]

77. Sarstedt, M.; Henseler, J.; Ringle, C.M. Multigroup analysis in partial least squares (PLS) path modeling: Alternative methods and empirical results. In Measurement and Research Methods in International Marketing; Emerald Group Publishing Limited: Bingley, UK, 2011.

78. Hair, J.F., Jr.; Sarstedt, M.; Hopkins, L.; Kuppelwieser, V.G. Partial least squares structural equation modeling (PLS-SEM): An emerging tool in business research. Eur. Bus. Rev. 2014, 2, 106-121. [CrossRef] 